\title{
Pneumologia
}

\section{Poorly controlled asthma: is it really asthma?}

Tito Abrantes*, João Silva

Abstract

Pulmonology Department, Centro Hospitalar Tondela-Viseu, 3504-509 Viseu, Portugal

English:

Abstract: Asthma is a common disorder, sometimes with nonspecific presenting features, which can lead to misdiagnosis. To obtain a definitive diagnosis of difficult-to-treat asthma, it should be ruled out non-adherence to prescribed therapy, other diagnosis or even psychiatric problems. The authors present two cases in which patients had symptoms that mimic asthma or complicated asthma management: foreign body aspiration mistaken as asthma and difficult-to-control asthma due to tracheal stenosis. Through this article, we recall the importance of anamnesis and differential diagnosis as key steps to the patient's best approach.

Keywords

asthma • anamnesis $\bullet$ differential diagnosis $\bullet$ foreign body $\bullet$ tracheal stenosis

\section{Astmul greu de controlat: este cu adevărat astm?}

Rezumat

\section{Romanian:}

Astmul este o boală des întâlnită, uneori cu manifestări nespecifice care pot duce la erori de diagnostic. Pentru a obține un diagnostic real al astmului dificil de tratat, trebuie înlăturate alte situații precum non-aderența la tratament sau alte diagnostice, inclusiv problemele psihiatrice. Autorii prezintă două cazuri în care pacienții au avut simptome care mimează astmul sau managementul astmului complicat: aspirația de corp străin, respectiv astmul dificil de controlat din cauza stenozei traheale asociate. Prin acest articol autorii semnalează rolul anamnezei corect efectuate și a diagnosticul diferențial ca pași importanți în modul de abordare al pacienților.

Cuvinte-cheie

astm • anamneză • diagnostic diferențial • corp străin • stenoză de trahee

\section{Introduction}

Bronchial asthma is a chronic inflammatory disease characterized by shortness of breath, wheezing, coughing, feeling of chest tightness, and a variable and reversible airflow obstruction in pulmonary function tests (PFTs) (1). The use of inhaled corticosteroids, with or without long-acting $\beta_{2}$ agonists and other drugs, in "step-up"/"step-down" approach, remains the mainstay of treatment (2). Two common causes for therapeutic failure in asthma are misdiagnosis and inability to recognize underlying contributing factors (3).

The authors report two cases of poorly controlled patients for a long period of time where asthma was not the correct diagnosis or the main pathology involved. Careful and attentive anamnesis is crucial for differential diagnosis.

\section{Cases report}

\section{First case}

The first case was a 29-year-old woman, a former smoker for 8 years (5 pack years), with a history of asthma diagnosed since childhood and hospitalization 10 years ago for community-acquired pneumonia complicated by left pleural effusion. She referred intermittent mucopurulent productive cough, dyspnoea and wheezing on exertion. In the last year, she had taken four cycles of empirical antibiotic therapy 
during her "asthma attacks", with only partial improvement. None of these episodes required hospital consultation. Her daily treatment was based on inhaled salmeterol and fluticasone in a high dose and salbutamol in exacerbations, taken two or three times a week. Previous allergy skin prick tests were negative. Initially, she denied recurrent pneumonia episodes and did not recall previous episodes of choking. The inhalation technique was correct.

The requested chest $\mathrm{X}$-ray revealed horizontalization of the ribs and an areolar image projected in the upper half of the left lung field (Figure 1). A further chest computed tomography (CT) scan was done and showed localized cylindrical bronchiectasis affecting the lingula, without signs of mucoid impaction or bronchial obstruction (Figure 2). Sputum samples send for microbiology and mycobacteriology were negative. PFTs showed only signs of small airway obstruction, and the bronchodilation test with salbutamol and the methacholine challenge test were both negative. Video fibrobronchoscopy was performed and revealed, at the entrance of the left upper lobe bronchus (LULB), a white and spherical-shaped lesion of hard consistency and irregular surface, suspicious of foreign body, practically with total lumen occlusion. Further rigid bronchoscopy was done and was able to extract the suspected foreign body (Figure 3).

At a resumption of anamnesis, she remembered an episode during her childhood when she choked on a pen cap after being pushed by her brother.

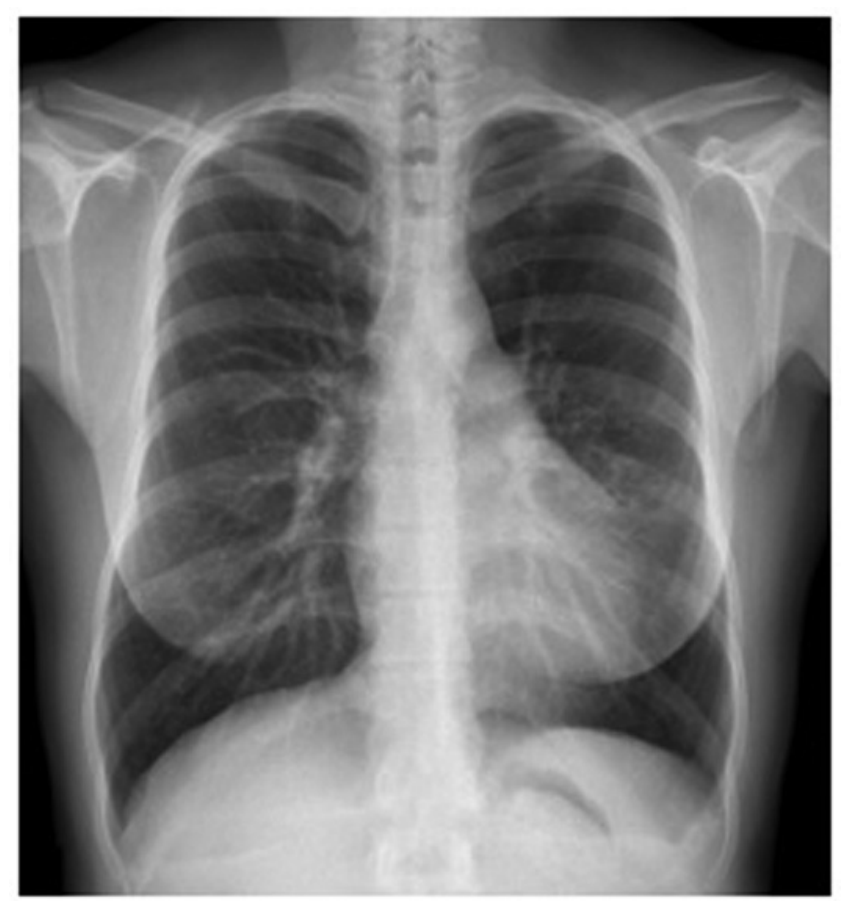

Figure 1. Chest X-ray. Signs of lung hyperinflation and upper left half of lung with areolar image.
Fibrobronchoscopy after 3 weeks showed marked endoscopic improvement with regression of the major inflammatory signs of LULB, and some mucopurulent secretions out flowed at this level.

The patient was then followed up, maintaining initially bronchodilator therapy and an inhaled corticosteroid. She was referred to respiratory kinesitherapy, and 4 months later, she was clinically improved and had only mucous secretions once in a while, with small airway obstruction on PFTs, so we descaled therapy only to salbutamol as needed.

\section{Second case}

The second case was a 67-year-old female, non-smoker, with no significant domestic or occupational exposure, with a history of mitral valvuloplasty 9 years ago and diagnosis of bronchial asthma since childhood controlled with inhaled formoterol and budesonide as maintenance and reliever therapy. The inhalation technique was correct. Clinically, she presented with morning shortness of breath, wheezing, hoarseness and chest tightening with slightly and progressive worsening in the last 5 years. Interpreted initially as deterioration of asthma, she was treated with montelukast, inhaled formoterol, tiotropium bromide and budesonide in high doses, without any improvement. PFTs showed obstructive dysfunction (Tiffeneau index of 0.62) with forced expiratory volume in the first second $\left(F E V_{1}\right)$ of $58 \%$, a positive bronchodilation test with salbutamol and an expiratory plateau on the flux-volume curve. Allergy skin tests were negative. Haemogram analysis and alpha-1antitrypsin were between the normal range. Chest CT was performed and revealed a reduction in the tracheal lumen in the proximal third with clear lung fields. So fibrobronchoscopy was done and showed irregular stenosis of the trachea in its upper third, beginning about $1 \mathrm{~cm}$ from the vocal cords, with a central hole of $8 \mathrm{~mm}$ in the smallest diameter (Figure 4).

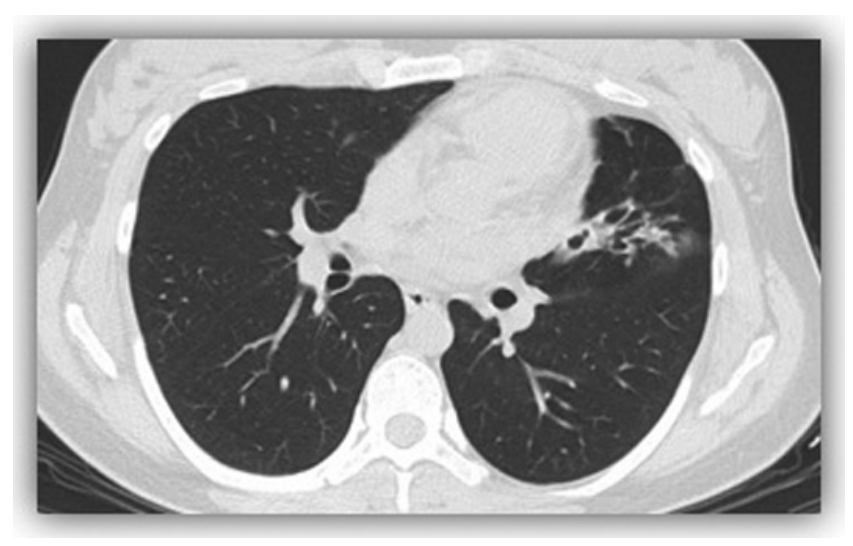

Figure 2. Chest CT (axial reconstruction). Localized cylindrical bronchiectasis in lingula. No noticeable bronchial obstruction or mucoid impaction was observed. 

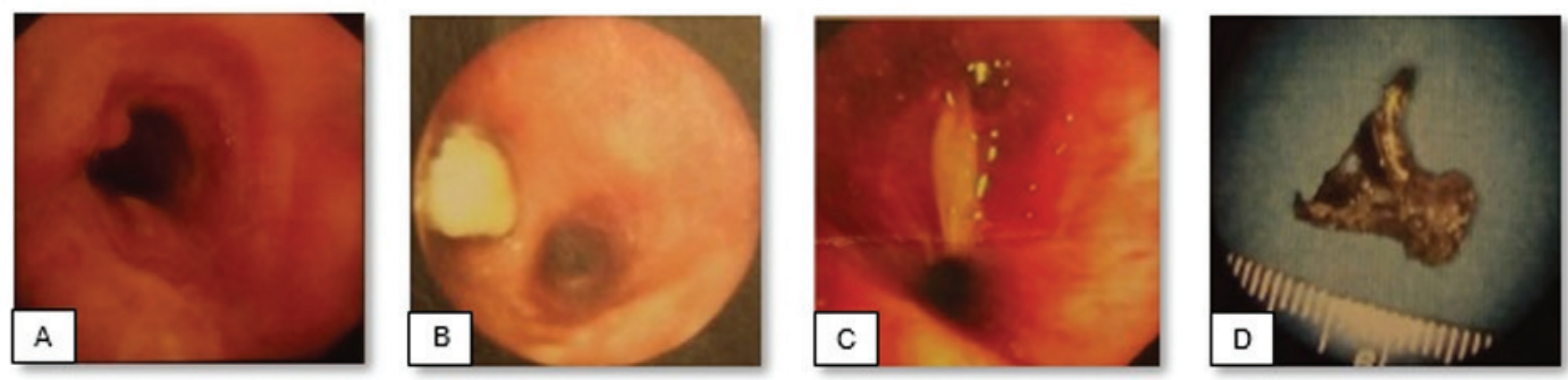

Figure 3. (A) Left main bronchus. (B) Left upper lobe bronchus (left) and left lower lobe bronchus (right). Foreign body surrounded by granulation tissue at LULB. (C) Left Upper Lobe Bronchus after foreign body extraction. Bronchial mucosal erythema and oedema. (D) Foreign body.

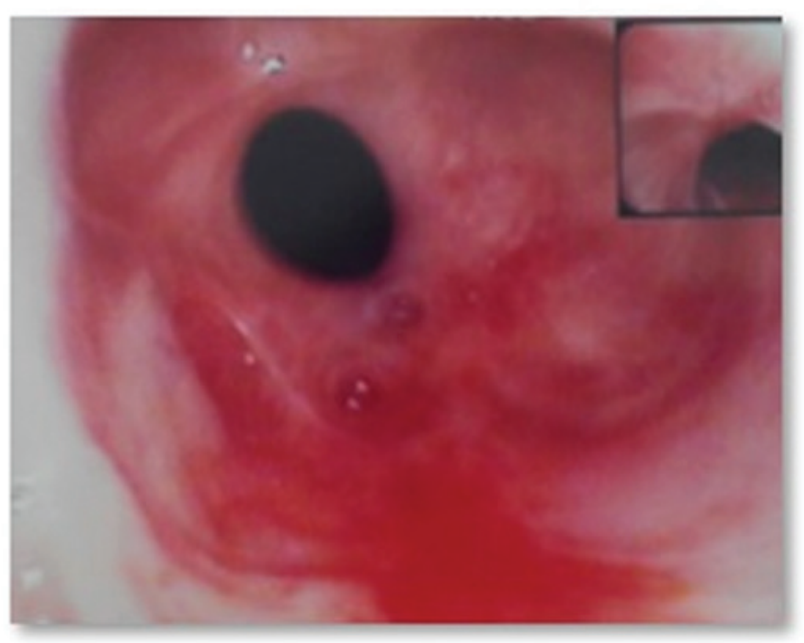

Figure 4. Videobronchofibroscopy. Subglottic tracheal stenosis related to previous intubation due to cardiac surgery.

Her case was discussed with the thoracic surgery team, and it was decided to perform surgical resection with excision of the second and third cartilage ring of the trachea and with anastomosis from top to bottom. A significant clinical improvement was achieved after surgery, and the patient remains with the previous lower dose of formoterol and budesonide, without any clinical deterioration. The latest PFTs showed improvement of $\mathrm{FEV}_{1} \%$ predicted $(71 \%)$ and Tiffeneau index (0.69).

\section{Discussion}

Asthma continues to be a very relevant pathology in terms of economic burden on health, morbidity and mortality, quality of life and scientific research (4). Several other pathologies may mimic this disease (5), so the integration of anamnesis data, complementary diagnostic examinations and clinical evolution present a challenge to the modern-day clinicians.
In both cases, patients had a previous diagnosis of asthma from their primary care physician and were treated with bronchodilators and inhaled corticosteroids. In the first case, the initial symptoms could be related to asthma, but the existence of mucopurulent secretions (almost daily), clinical deterioration despite treatment for asthma, minor changes on PFTs, negative bronchodilation and methacholine tests and abnormal chest $\mathrm{X}$-Ray raised the suspicion of a different diagnosis. The chest CT showed localized bronchiectasis with distribution suggestive of a bronchial obstructive lesion or post-infective bronchiectasis (6). The bronchial obstruction could not be seen in the chest CT, and the history of previous pneumonia in lingula could explain the presence of bronchiectasis. Even so, fibrobronchoscopy was performed and confirmed a bronchial lesion, further recognized as a pen cap, meaning that the patient probably never had asthma and the symptomatology was a consequence of this finding. The clinical improvement, even after inhaled corticosteroid suspension, helps us to confirm this hypothesis.

The second presented case was a patient with a previously established diagnosis of asthma, well controlled with inhalers. Clinical deterioration was observed, and there was no answer to asthma upscale treatment. Besides the PFTs that showed airway obstruction with the positive bronchodilation test, the existence of daily symptoms, worsening over time, hoarseness and the flattened expiratory curve raised the suspicion of an additional diagnosis, which was confirmed on chest CT. In this case, previous intubation during cardiac surgery comes up as the best explanation for the tracheal stenosis, a relatively rare but serious problem (7). In this patient, asthma still remains the main diagnosis, as PFTs continued to show airway obstruction in the presence of a history of clinical manifestations of asthma before the cardiac surgery.

\section{Conclusions}

These cases show that is necessary to maintain a high index of suspicion of alternative diagnoses when evaluating a patient 
with clinical characteristics suggestive of asthma, particularly if the patient shows atypical symptoms or does not respond to optimized therapy (8). Previous asthma diagnosis can be incorrect (first case) or concomitant with another respiratory condition (second case).

\section{Ethics approval and consent to participate}

Inform consent was obtained from the patients in order to write the article.

\section{Consent for publication}

Consent was obtained from the patients for publication of this case report and accompanying images.

\section{Conflicts of interest}

The authors declare that they have no conflicts of interest.

\section{References}

1. Global Initiative For Asthma (GINA). Global strategy for asthma management and prevention. Global Initiative for Asthma. 2017;14.

2. Reddel HK. Goals of asthma treatment: How high should we go? European Respiratory Journal. 2004;24(5): 715-717.

3. Amundson D, Seda G, Daheshia M. Recognizing asthma mimics and asthma complications. Military Medicine. 2011;176(10): 1162-1168.

4. Morjaria JB, Kastelik JA. Unusual asthma syndromes and their management. Therapeutic Advances in Chronic Disease. 2011;2(4): 249-264.

5. Tilles SA. Differential diagnosis of adult asthma. Medical Clinics of North America. 2006;90(1): 61-76.

6. Contarini M, Finch S, Chalmers JD. Bronchiectasis: a casebased approach to investigation and management. European Respiratory Review. 2018;27(149): 180016.

7. De S, De S. Post intubation tracheal stenosis. Indian Journal of Critical Care Medicine. 2008;12(4): 194-197.

8. King CS, Moores LK. Clinical Asthma syndromes and important asthma mimics. Respiratory Care. 2008;53(5): 568 LP-582 LP. 